University of Nebraska - Lincoln

DigitalCommons@University of Nebraska - Lincoln

Faculty Publications from the Harold W. Manter Laboratory of Parasitology

8-1966

\title{
Studies on American Paragonimiasis. IV. Observations on the Pairing of Adult Worms in Laboratory Infections of Domestic Cats
}

Franklin Sogandares-Bernal

Southern Methodist University, fsogandares@wildblue.net

Follow this and additional works at: https://digitalcommons.unl.edu/parasitologyfacpubs

Part of the Parasitology Commons

Sogandares-Bernal, Franklin, "Studies on American Paragonimiasis. IV. Observations on the Pairing of Adult Worms in Laboratory Infections of Domestic Cats" (1966). Faculty Publications from the Harold W. Manter Laboratory of Parasitology. 478.

https://digitalcommons.unl.edu/parasitologyfacpubs/478

This Article is brought to you for free and open access by the Parasitology, Harold W. Manter Laboratory of at DigitalCommons@University of Nebraska - Lincoln. It has been accepted for inclusion in Faculty Publications from the Harold W. Manter Laboratory of Parasitology by an authorized administrator of DigitalCommons@University of Nebraska - Lincoln. 


\title{
STUDIES ON AMERICAN PARAGONIMIASIS. IV. OBSERVATIONS ON THE PAIRING OF ADULT WORMS IN LABORATORY INFECTIONS OF DOMESTIC CATS*
}

\author{
Franklin Sogandares-Bernal \\ Laboratory of Parasitology, Department of Biology, Tulane University, New Orleans, Louisiana
}

ABSTRACT: Observations are reported on the pairing of Paragonimus kellicotti Ward, 1908, in laboratory infections of 19 domestic cats. In four of six cases in which single metacercariae were fed 8 weeks previous to subsequent reexposure to another metacercaria, the worms were able to locate one another and become established in the lung cyst of the definitive host and the infections became patent. The role of pairing and the attraction between worms is discussed.

During work on Paragonimus kellicotti Ward, 1908 , being conducted in my laboratory, an effort was made to study the pairing of adult worms in the lung cyst of the domestic cat.

\section{METHODS}

Laboratory infections of $P$. kellicotti were maintained as described by Sogandares (1965). Metacercariae from second-, third-, and fourth-generation laboratory infections were fed to domestic cats which had been determined to be free of infection by fecal examinations using sedimentation-concentration and Telemann's (1908) techniques. The experimental animals were fed varied numbers of metacercariae. One group of cats received one metacercaria followed by another after a period of 8 weeks during which time the infections had not become patent.

The cats were killed either soon after the infections became patent or after a period of several months. The lungs were then carefully examined for cysts and the numbers of worms in each cyst were counted. In the case of the two-metacercariae experiments, if two adult worms were not recovered in a cyst, the lung was carefully examined for migrating preadults.

\section{RESULTS}

Table I shows results obtained from the exposure of 19 domestic cats to metacercariae of $P$. kellicotti. These data show that the recovery rates of adult worms versus metacercariae fed are variable; also that in four of the six cases in which a single metacercaria was fed 8 weeks subsequent to previous exposure to a single metacercaria (cited as $1+1=2$ in table), the worms were able to locate one another and become established in cysts in the

Received for publication 22 April 1966.

* Supported in part by research grants from the NIH (AI-03386-06) and National Science Foundation (GB-3036). lung of the host and the infection became patent. It is also apparent that in the majority of cases there were two worms per lung cyst; but in other cases three, four, five, or six worms were found in a single cyst in the given order of frequency. Even though odd numbers of adult worms were recovered in the lungs of infected hosts, there was no instance in which a single adult worm was found in a host lung cyst. When single worms were found, these were preadults migrating in the lobules of the host lung or directly under the serosal membranes covering the lung; this, in spite of the fact that enough time had elapsed for normal development to the egg production stage if two or more worms had been together in a lung cyst. No instance of ectopic location of worms was observed in these experiments.

\section{DISCUSSION}

Yokogawa (1919a, b) observed during experimental infections of dogs and cats with Paragonimus westermani (Kerbert, 1878) that preadults often migrate in pairs, especially in the host pleural cavities and during penetration of the lungs. He also observed that there were almost always two worms per host lung cyst. Ameel (1934) also observed, in experimental infections of white rats, cats, dogs, and pigs, with $P$. kellicotti, that two worms were usually found in each lung cyst. He noted, however, that overcrowding often raised the numbers of worms per lung cyst in white rats and cats. My data on cats (Table I) seem to be in general agreement with Ameel's findings on $P$. kellicotti. Chen (1940) studied infections of $P$. iloktsuensis Chen, 1940, in rats, and reported two worms per lung cyst, but he also observed that it was not unusual to recover 
TABLE I. P. kellicotti infections of domestic cats.

\begin{tabular}{|c|c|c|c|c|c|c|c|c|}
\hline \multirow{3}{*}{$\begin{array}{c}\text { Cat } \\
\text { number }\end{array}$} & \multirow{3}{*}{$\begin{array}{c}\text { Exposure } \\
\text { Numbers of } \\
\text { metacercariae }\end{array}$} & \multirow{3}{*}{$\begin{array}{c}\text { Recovery } \\
\text { Adult } \\
\text { worms }\end{array}$} & \multicolumn{6}{|c|}{$\begin{array}{c}\text { Number of worms pe } \\
\text { lung cyst }\end{array}$} \\
\hline & & & 1 & 2 & 3 & 4 & 5 & 6 \\
\hline & & & \multicolumn{6}{|c|}{$\begin{array}{l}\text { Numbers of cysts } \\
\text { in cat lung }\end{array}$} \\
\hline 3 & 15 & 7 & & 2 & 1 & & & \\
\hline 7 & 21 & 21 & & 6 & 3 & & & \\
\hline 9 & $1+1=2 *$ & 2 & & 1 & & & & \\
\hline 10 & 15 & 13 & & 5 & 1 & & & \\
\hline 13 & 30 & 26 & & 10 & 2 & & & \\
\hline 15 & 15 & 8 & & 4 & & & & \\
\hline 16 & 5 & 2 & & 1 & & & & \\
\hline 17 & 30 & $\overline{9}$ & & 3 & 1 & & & \\
\hline 18 & 30 & 21 & & 3 & 2 & 1 & 1 & \\
\hline 20 & 5 & 2 & & 1 & & & & \\
\hline 21 & 30 & $1 \overline{6}$ & & 2 & 1 & 1 & 1 & \\
\hline 22 & 30 & 27 & & $\overline{9}$ & 3 & & & \\
\hline 23 & 40 & 22 & & 6 & 2 & 1 & & \\
\hline 24 & 40 & 30 & & 12 & & & & 1 \\
\hline 25 & $1+1=2 *$ & 0 & & & & & & \\
\hline 27 & $1+1=2 *$ & 2 & & 1 & & & & \\
\hline 28 & $1+1=2 *$ & 0 & & & & & & \\
\hline 29 & $1+1=2 *$ & 2 & & 1 & & & & \\
\hline 30 & $1+1=2^{*}$ & 2 & & 1 & & & & \\
\hline Totals & 318 & 212 & & 68 & 16 & 3 & 2 & 1 \\
\hline
\end{tabular}

* Second metacercaria fed 8 weeks after first.

one, three, or five worms per lung cyst. Yokogawa, Oshima, and Yoshimura (1956) exposed eight puppies each to single metacercariae of $P$. westermani, but recovered only three preadults in the pleural cavities of these hosts after 12 and 20 weeks of infection. These data are in contrast with those of Yokogawa, Yoshimura, Koyama, Sano, Tsuda, and Tsuji (1958) who fed rats single metacercariae of P. ohirai Miyazaki, 1939, and recovered mature worms from the pleural cavities, but not lungs, of $47 \%$ of 40 rats used in the experiments. In my own studies of $P$. kellicotti single worms were recovered as migrating preadults long after ( 16 weeks) the normal time span (4 to 6 weeks) in which two or more worms would have developed to maturity in their lung cysts. Yokogawa, Cort, and Yokogawa (1960) remarked, "It has been assumed that the travelling of the worms in pairs as they approach sexual maturity and the usual presence of two in a cyst are sexual phenomena related to cross fertilization." Chen (1937) studied the process of oogenesis in P. kellicotti and indicated that the spermatozoon must penetrate the oocyte before maturation division, along with normal extrusion of polar bodies, can occur. The oocytes are penetrated by the spermatozoon in the oviduct and shortly thereafter become shelled, presumably in the ootype. He reported a haploid chromosome number of 8 and a diploid number of 16 . Chen's studies leave little doubt that $P$. kellicotti must normally mate, be it self-mating or cross-mating, before fertile eggs can be produced. However, the process of gynogenesis in self-matings needs further exploration. Yokogawa, Cort, and Yokogawa (1960) have indicated that in human infections of $P$. westermani single worms are found in the host lung cysts, but to my knowledge uterine eggs of single worm infections have never been tested for viability through to the adult stage. The fact that adult worms were not found living singly in their final habitat in the lungs of the definitive hosts in my experiments is not conclusive evidence that cross-fertilization is necessary. However, single worms, when found (see above) were migrating preadults long after they would have developed to maturity had they been paired in the host lung cyst.

It is premature to speculate as to the mechanism involved, but there is no question about the frequency with which these worms find each other in experiments where a second metacercaria is fed about 8 weeks after the first. This problem is being studied further. The possibility of chemical attractants produced by preadults should not be ignored, but these may be found to work indirectly through the host's immune response system.

\section{LITERATURE CITED}

AmeeL, D. J. 1934. Paragonimus, its life history and distribution in North America and its taxonomy (Trematoda: Troglotrematidae). Am. J. Hyg. 19: 279-317.

Chen, H. T. 1940. Morphological and developmental studies of Paragonimus iloktsuensis with some remarks on other species of the genus (Trematoda: Troglotrematidae). Lingnan J. Sci. 19: 429-530.

Chen, P. D. 1937. The germ cell cycle in the trematode Paragonimus kellicotti Ward. Tr. Am. Micr. Soc. 56: 208-236.

Sogandares-Bernal, F. 1965. Studies on American paragonimiasis. I. Age immunity of the snail host. J. Parasit. 51: 958-960.

Telemann, W. 1908. Eine Methode zur Erleichterung der Auffindung von Parasiteneiern in den Faeces. Deut. Med. Wschr. 34: 15101511.

Yokogawa, S. 1919a. Hai distoma no kenyu (Studies on lung distomes). 3. Rep. Endoparasitic Dis. Research in Taiwan, 289 p. (Japanese text.) 
1919b. Studien ueber die Uebergangsund Verbreitungswege des Paragonimus westermanni Kerbert (Distoma pulmonale Baelz). In Koerper des Endwirtes. Verlag von Generalregierung von Formosa, 38 p. (no place of publication given).

$\longrightarrow$, W. W. Cont, ANd M. Yokogawa. 1960. Paragonimus and paragonimiasis. Exp. Parasit. 10: 81-137, 139-205.

Yokogawa, M., T. Oshima, and H. Yoshimura.
1956. Experimental infection of the puppies with single metacercaria of Paragonimus westermani. Jap. J. Parasit. 5: 255-256. (Japanese text.)

, H. Yoshimura, C. Koyama, M. Sano, M. TsudA, AND M. Tsuji. 1958. Experimental infection in rats with single metacercaria of Paragonimus ohirai. III. Formation of the worm cysts and histological changes of the lungs. Jap. J. Parasit. 7: 301. (Japanese text.) 